\title{
Customer Service in the Residential Property Market of South Africa
}

\author{
Sharon Rudansky-Kloppers and Johan Strydom
}

School of Business Management, Unisa

\section{ABSTRACT}

An increasing number of estate agencies are entering the real estate market in South Africa and many are struggling to survive as competition grows stronger. Customer service has become of overriding importance to establish a differential advantage that will ensure long-term survival. This study investigates customer service by estate agencies in the residential property market of South Africa. The results indicate that estate agencies seem to be aware of the importance of providing good customer service and of being service-oriented, but they do not always seem to realise the need to conduct marketing research and test the actual satisfaction of customers with the services provided, leaving a potential gap between what the customer wants and what the estate agency provides.

JEL L85

\section{INTRODUCTION}

Buying a home is one of the major events in the life of most individuals. It is usually the single largest financial decision that a household makes and often it is a once in a lifetime event. For most people the experience is physically tiring and mentally draining.

In the majority of cases, estate agents are the people who not only play the leading role when it comes to buying a home, but - as a group of people probably exert the single largest influence of any group during this process. Their guidance, knowledge, assistance and the way they conduct and execute their duties can have a profound effect on the buyer and the seller, and ultimately on whether or not a house is sold. The position of the estate agent could thus be regarded as a vital factor in the buying and selling of property.

The estate agency industry has an exceptionally high personnel turnover, that is, influx and departure, of sales staff (verbal communication with the Estate Agency Affairs Board). According to experts in the industry, it is generally 
accepted that approximately 40 per cent of the industry is leaving while another 40 per cent is joining at any given time (verbal communication with the Estate Agency Affairs Board). Estate agents seem to have such high expectations of making millions within a short period, that when their expectations are not met, they tend to leave the industry. This generally results in poor customer service. Building good relationships with customers is a crucial aspect of any selling situation. The estate agent can thus determine the potential customer's needs, demands and preferences and therefore only show him ${ }^{1}$ homes that fall into the category he prefers. Ultimately, by taking cognisance of the customer's needs and rendering good customer service, the estate agent will receive his commission. Even if the customer does not require a new home himself, a satisfactory encounter with an agent may result in good word-of-mouth communication about the agent.

However, there is some concern about the customer service which estate agents and agencies currently offer to customers. According to Futrell (2000: 379), customer service refers to the activities and programmes provided by the seller to make the relationship satisfying for the customer. Lewison (1997: 492) defines it as all the "features, acts and information that augment the customer's ability to realize the potential value of a core product or service". Very little research has been done in the past on estate agencies and particularly on their provision of customer service. This article provides more insight into this problem and presents the opinions of residential estate agencies on customer service.

\section{BACKGROUND}

Entry of estate agents into the industry was made easier in April 1994 when it was announced that it was no longer compulsory for estate agents to write the Estate Agency Affairs Board examination. This examination was first introduced in 1984 and covers all aspects of the estate agency industry (verbal communication with the Estate Agency Affairs Board (EAAB). Prospective estate agents may now register with the Board and serve what is known as a one-year candidate period, after which they are registered as estate agents. The comparative ease with which estate agents can now enter the market is, however, a matter of great concern to estate agents who have been in the industry for many years. They contend that the compulsory examination was appropriate because the estate agent deals with large monetary investments and this requires extreme professional service on the part of the estate agent.

The impetus for the study came from the realisation that increasingly more estate agencies are entering the real estate market in South Africa, and many are 
struggling to survive as competition grows stronger (verbal communication with the EAAB). Customer service becomes of overriding importance in an environment in which these businesses try to survive and compete with one another. Hence, if they wish to establish a differential advantage that will ensure long-term survival, estate agencies will have to learn more about the effective marketing of their services, with the emphasis on rendering excellent customer service. According to Kurtz and Clow (1998: 308) a differential advantage is some feature or attraction which competitive offerings lack, that will provide satisfaction or understandable benefits to buyers.

Since estate agents are the principal asset and financial investment of an estate agency firm, no estate agency can grow in size and prosper without qualified, professional, motivated and devoted estate agents (verbal communication with the EAAB). The estate agency, therefore, has to be able to attract successful or potentially successful estate agents. Human resource management in the estate agency business is thus of the utmost importance. If such management is not conducted properly, unsuitable estate agents could be recruited who may not be able to conduct the selling process effectively, provide customer service and develop enduring relationships with customers, which ultimately means lost business and a bad reputation for the firm.

Hence, customer service is a critical feature of the estate agency industry. Good service pays off because it creates true clients, namely clients who are glad they selected a particular estate agency, customers who will use the estate agency again and sing the agency's praises to family and friends, who in turn may become loyal clients.

In South Africa, 68 per cent of customers who leave a company do so because they are dissatisfied with the service they are receiving (Cheales, 2000: 6). As early as 1987, Le Boeuf (1987: 13-14) realised the importance of good customer service with the following finding: "A typical business hears from only four per cent of its dissatisfied customers. The other ninety six per cent just quietly go away and ninety one per cent will never come back".

According to Truter (1993: 20), the provision of good customer service is a key success factor of estate agencies in South Africa. In order to render quality service, estate agents should be knowledgeable and informed. An agent should not be tardy in offering customers the benefit of his expertise, even on an informal basis, because this will add value to the service provided, thus improving the chances of creating a differential advantage.

Estate agents are sometimes regarded as fly-by-nights by the general public, who perceive them to be intruders who make easy money. It is, therefore, up to 
the members of the profession to change this perception by building a sound reputation through the quality of the service they render. Truter (1993: 20) indicates that the maintenance of high ethical standards and inherently good customer service throughout the whole selling process, can help convince the public that estate agents are not parasites and work hard to earn their money.

Simple practicalities and sound logistics are an integral part of customer service. No estate agent who forgets appointments, arrives late, has insufficient information available, or appears to be disorganised, is rendering a good service. Quality service makes a solid contribution towards a good professional reputation and helps to retain customers instead of simply "getting" them.

There are numerous definitions of service quality, but quality is generally viewed in the light of the functions which a product or service must deliver (consumer need satisfaction). Futrell (2000: 379) indicates that the quality of service must be based on customer expectations. Customers expect a certain level of service from the seller. Their expectations are frequently based on information provided by the salesperson, past experiences, word-of-mouth and personal needs. When buyers perceive the service they receive as the kind of service they expected, they are satisfied.

According to Kotler (2000: 438), when expectations are exceeded, service is perceived to be of exceptional quality and also to be a pleasant surprise. Conversely, when expectations are not met, service quality is deemed to be unacceptable. When expectations are confirmed by perceived service, quality is satisfactory.

Pride and Ferrell (2000: 331) also contend that service quality is an indication of how well the service level delivered matches customer expectations and that the provision of quality service means consistently conforming to customer expectations. These authors indicate that service quality is the difference between consumers' expectations of a service and the service they actually receive.

With the above as background, it was decided to conduct research into the views of South African residential estate agencies on customer service and their perceptions of their delivery of customer service. The research objectives were to determine:

- $\quad$ the profile of the estate agencies investigated;

- $\quad$ whether estate agencies have mission statements which refer to factors such as customer need satisfaction and customer service;

- $\quad$ whether estate agencies regard the principles of the marketing concept as important; 
- $\quad$ whether estate agencies consider the service orientation of estate agents during the selection, appointment and training of agents;

- the differentiation methods used by estate agencies to establish a competitive advantage;

- $\quad$ the after-sales services offered by estate agents;

- $\quad$ specific activities engaged in by estate agencies in order to ensure customer service;

- $\quad$ the corporate climate and internal marketing activities of estate agencies;

- $\quad$ the policies of estate agencies on customer complaints.

\section{METHODOLOGY}

The data were collected by means of a mail questionnaire (addressed to the owner/manager) that was posted to 8121 estate agencies (the population) in South Africa who were all officially registered with the EAAB. The research design was, therefore, a census instead of a sampling procedure (Jankowicz, 2001: 198). The questionnaire contained screening questions which eliminated all returned questionnaires that did not involve residential estate agencies. The total number of returned questionnaires for residential estate agencies was 486, all of which were completed by either the owner or manager of the estate agency. These questionnaires were thus used to analyse the results. The data were subsequently captured and analysed by means of the statistical software program SAS (Statistical Analysis System). Various statistical analyses were conducted on the data in order to facilitate a discussion of the research results. Cross-tabulations were also used to determine the effect of certain dependent variables on certain independent variables. For these purposes, a one-way frequency distribution was constructed that showed the frequency incidence of selected main variables in terms of absolute and relative values.

\section{ANALYSIS AND RESULTS}

The analysis and results will be discussed in the same sequence as the objectives formulated earlier in the study.

\section{- $\quad$ Profile of the estate agencies}

The study revealed that the majority of estate agencies that were investigated are close corporations, while sole proprietorships constitute the second most popular form. Most of the agencies (79,9 per cent) employ between one to 10 agents and between one to five support personnel. The majority of agencies have one to two directors. The findings reveal that the most popular target market for the agencies is middle-class families, followed by upper-class 
suburbs, while the third most popular target market is first-time buyers.

- $\quad$ Mission statement

A mission statement describes the nature of the organisation's activities. The results indicate that most of the respondents do not know what a mission statement is. It should be possible to derive the following answers from a mission statement (Strydom et al., 2000: 477):

- What is the nature of the business undertaken by the enterprise?

- Who are the consumers?

- What are these consumers' needs?

- What is the nature of the internal resources and abilities at the disposal of the enterprise?

- $\quad$ How can the enterprise satisfy consumer needs?

- What environmental factors have to be taken into consideration?

Although a large percentage of respondents (51 per cent) indicated that they do have mission statements, it was found that only seven respondents seem to have mission statements which meet some of the theoretical requirements for a mission statement. The rest of the respondents seem to regard a mission statement as a slogan or objective. The findings indicate that most respondents (68,5 per cent) who have "mission statements" communicate them to their agents by means of training sessions and advertising and promotions. What is thus communicated to the agents, is not the nature of the enterprise's activities and the organisation's raison d'être in the light of long-range opportunity, but short-term sales objectives. In fact, in most instances the message conveyed could create more confusion for the agents, instead of helping them to understand the purpose of the enterprise.

- $\quad$ The marketing concept

In terms of the marketing concept - a managerial code or philosophy guiding an organisation's entire activities - an estate agency can only be effective and efficient if it accepts and applies the four principles of the marketing concept, namely consumer orientation, profit orientation, systems orientation and social responsibility orientation. The survey results reveal that the majority of respondents regard the four principles as vitally important. Systems orientation was ranked first, consumer orientation second, and a long-term approach to profitability, third. The fact that consumer orientation was ranked second indicates that estate agencies do seem to regard the consumer and his needs as important.

- $\quad$ Selection, appointment and training of new agents

No estate agency can grow and prosper without qualified, professional, 
motivated and devoted estate agents. The study reveals that when hiring new agents, the majority of agencies (86,6 per cent $+6,2$ per cent $=92,8$ per cent) always or frequently consider the agent's ability to work with clients when hiring employees. Hardly any agencies do not consider this as an important variable.

The criteria which estate agencies use when appointing new estate agents were also investigated. The unit of measurement used in the questionnaire design mainly allowed for the generation of ordinal data (rating questions). This allowed for a typical descriptive analysis option with the arithmetic mean as the ideal method. The mean was defined by the sum of all sets of values divided by the number of observations. The means in Table 1 indicate that honesty/integrity $(3,91)$ and interpersonal skills $(3,76)$ are viewed as most important and second most important criteria when appointing new estate agents. Personality $(3,68)$ and service orientation $(3,67)$ are ranked third and fourth by estate agencies as criteria for appointing new estate agents. Since 84,3 per cent always or frequently consider service orientation when appointing new agents, customer service thus seems to be significant for estate agencies. The criteria seen as least important by respondents are completion of the Board examinations $(3,03)$, education and previous training $(3,00)$, previous experience $(2,74)$ and aggressiveness $(2,70)$. It would thus appear that estate agencies are not overly concerned about qualifications or experience in the field of real estate when appointing new agents.

Table 1 Criteria used to appoint new estate agents

\begin{tabular}{|l|c|c|c|c|c|c|}
\hline \multicolumn{1}{|c|}{ Statements } & $\begin{array}{c}\text { Never } \\
\mathbf{\%}\end{array}$ & $\begin{array}{c}\text { Sel- } \\
\mathbf{d o m} \\
\mathbf{\%}\end{array}$ & $\begin{array}{c}\text { Fre- } \\
\text { quently } \\
\mathbf{\%}\end{array}$ & $\begin{array}{c}\text { Always } \\
\mathbf{\%}\end{array}$ & Mean & $\begin{array}{c}\text { No re- } \\
\text { sponse } \\
\mathbf{\%}\end{array}$ \\
\hline $\begin{array}{l}\text { Honesty/integrity } \\
\begin{array}{l}\text { Interpersonal skills in } \\
\text { dealing with clients }\end{array}\end{array}$ & 0,8 & 0,6 & 4,3 & 87,2 & 3,91 & 7,1 \\
\hline Personality & 2,5 & 14,4 & 73,0 & 3,76 & 9,3 \\
\hline Service orientation & 0,8 & 2,1 & 22,4 & 66,0 & 3,68 & 8,7 \\
\hline Courtesy & 0,6 & 2,7 & 22,6 & 61,7 & 3,67 & 12,6 \\
\hline Practicalities (eg transport) & 2,3 & 4,7 & 15,2 & 65,4 & 3,64 & 12,4 \\
\hline Appearance & 0,6 & 3,7 & 27,0 & 59,7 & 3,60 & 9,0 \\
\hline Ambition & 1,0 & 4,7 & 28,2 & 53,3 & 3,53 & 12,8 \\
\hline $\begin{array}{l}\text { Creativity in presenting the } \\
\text { property to buyers }\end{array}$ & 1,9 & 9,3 & 30,7 & 45,3 & 3,37 & 12,8 \\
\hline
\end{tabular}




\section{Table 1 continued}

\begin{tabular}{|l|c|c|c|c|c|c|}
\hline \multicolumn{1}{|c|}{ Statements } & $\begin{array}{c}\text { Never } \\
\mathbf{\%}\end{array}$ & $\begin{array}{c}\text { Sel- } \\
\mathbf{d o m} \\
\mathbf{\%}\end{array}$ & $\begin{array}{c}\text { Fre- } \\
\text { quently } \\
\mathbf{\%}\end{array}$ & $\begin{array}{c}\text { Always } \\
\mathbf{\%}\end{array}$ & Mean & $\begin{array}{c}\text { No re- } \\
\text { sponse } \\
\mathbf{\%}\end{array}$ \\
\hline Judgement ability & 1,9 & 9,7 & 38,1 & 37,0 & 3,27 & 13,3 \\
\hline $\begin{array}{l}\text { Physical stamina to perform } \\
\text { well }\end{array}$ & 4,1 & 16,9 & 29,4 & 31,0 & 3,07 & 18,6 \\
\hline $\begin{array}{l}\text { Completion of the Board } \\
\text { examinations }\end{array}$ & 8,0 & 18,7 & 23,5 & 37,0 & 3,03 & 12,8 \\
\hline $\begin{array}{l}\text { Education and previous } \\
\text { training }\end{array}$ & 4,5 & 19,1 & 36,6 & 27,8 & 3,00 & 12,0 \\
\hline $\begin{array}{l}\text { Previous experience } \\
\text { Aggressiveness }\end{array}$ & 9,1 & 24,5 & 34,6 & 19,5 & 2,74 & 12,3 \\
\hline \hline
\end{tabular}

The results on the training process reveal that a large percentage (63,6 per cent) of estate agencies train estate agents themselves. Of the respondents, 31,3 per cent are of the opinion that on-the-job training is adequate for agents, while only 25,1 per cent sponsor further study programmes for their estate agents. Very few estate agencies (5,6 per cent) feel that no formal training is needed.

Table 2 indicates the focal areas in the training of estate agents. The high means obtained for all the training aspects indicate that most respondents always concentrate on all the areas mentioned in this question. Professionalism rated a mean of 3,87, while the code of conduct of the EAAB was rated second (mean $=3,84)$. Qualifying the buyer/seller (mean $=3,69$ ) and legislation (mean $=3,68$ ) were rated third and fourth respectively. Factors such as building long-term relationships with clients (mean $=3,62$ ) and after-sales contact with the buyer/seller (mean $=3,58$ ) also rated high means, which is encouraging since these are key components of customer service.

Table 2 Focal areas in the training of estate agents

\begin{tabular}{|l|c|c|c|c|c|c|}
\hline Training areas & $\begin{array}{c}\text { Never } \\
\mathbf{\%}\end{array}$ & $\begin{array}{c}\text { Sel- } \\
\text { dom } \\
\mathbf{\%}\end{array}$ & $\begin{array}{c}\text { Fre- } \\
\text { quently } \\
\mathbf{\%}\end{array}$ & $\begin{array}{c}\text { Always } \\
\mathbf{\%}\end{array}$ & Mean & $\begin{array}{c}\text { No re- } \\
\text { sponse } \\
\mathbf{\%}\end{array}$ \\
\hline Professionalism & 0,6 & 0,2 & 8,0 & 73,0 & 3,87 & 18,2 \\
\hline $\begin{array}{l}\text { Code of conduct of the Estate } \\
\text { Agency Affairs Board }\end{array}$ & 0,4 & 2,3 & 7,8 & 71,8 & 3,84 & 17,7 \\
\hline Qualifying the buyer/seller & 0,6 & 2,3 & 18,5 & 59,1 & 3,69 & 19,5 \\
\hline Legislation on estate agents & 0,6 & 3,5 & 16,3 & 59,3 & 3,68 & 20,3 \\
\hline Inspecting the property & 1,0 & 3,7 & 16,5 & 60,3 & 3,67 & 18,5 \\
\hline Knowledge of the market & 0,8 & 1,2 & 23,0 & 56,0 & 3,65 & 19,0 \\
\hline
\end{tabular}


Table 2 continued

\begin{tabular}{|l|c|c|c|c|c|c|}
\hline Training areas & $\begin{array}{c}\text { Never } \\
\mathbf{\%}\end{array}$ & $\begin{array}{c}\text { Sel- } \\
\text { dom } \\
\mathbf{\%}\end{array}$ & $\begin{array}{c}\text { Fre- } \\
\text { quently } \\
\mathbf{\%}\end{array}$ & $\begin{array}{c}\text { Always } \\
\mathbf{\%}\end{array}$ & Mean & $\begin{array}{c}\text { No re- } \\
\text { sponse } \\
\mathbf{\%}\end{array}$ \\
\hline $\begin{array}{l}\text { Building long-term relationships } \\
\text { with clients }\end{array}$ & 0,8 & 4,5 & 19,3 & 56,8 & 3,62 & 18,6 \\
\hline $\begin{array}{l}\text { Assisting the buyer in obtaining } \\
\text { finance }\end{array}$ & 0,8 & 4,1 & 21,0 & 55,3 & 3,61 & 18,8 \\
\hline $\begin{array}{l}\text { After-sales contact with the } \\
\text { buyer/seller }\end{array}$ & 1,2 & 3,3 & 24,1 & 53,3 & 3,58 & 18,1 \\
\hline How to work with mandates & 1,9 & 2,7 & 25,7 & 49,6 & 3,54 & 20,1 \\
\hline The personal selling process & 1,2 & 3,3 & 27,6 & 47,9 & 3,53 & 20,0 \\
\hline Showing selected properties & 1,0 & 6,0 & 25,5 & 46,5 & 3,49 & 21,0 \\
\hline Advertising the property & 2,1 & 5,8 & 28,0 & 45,3 & 3,44 & 18,8 \\
\hline
\end{tabular}

In order to provide good customer service, the estate agent should take certain consumer-behaviour influences into account when attempting to sell his services. It was thus essential to determine whether customer-behaviour factors are also covered in the training programmes of estate agencies. Table 3 reveals that on the three-point scale, the two factors which are discussed in greater detail than the others at training sessions, are buyers' income/financial status (mean $=2,33$ ) and buyers' reasons for buying property (mean $=2,30$ ). All the other factors rated means of less than two and are not discussed in great detail at training sessions. These include socio-demographic factors, learning and perceptual ability, pressure from social groups, the buyer's lifestyle and the influence of the family. It is worrying that these factors are not included in training programmes to a greater extent, because agents need to be aware of them in order to render satisfactory customer service. Cross-tabulations indicate a link between those agencies concentrating on the buyer's income or financial status, at the same time claiming that they are consumer-oriented. However, these respondents sometimes appear to concentrate more on the buyer's financial position than on his actual needs and the consumer behaviour influences. In order to be consumer-oriented and to provide excellent customer service, estate agencies need to concentrate on all the consumer behaviour influences and not only on financial means which is but one group of consumer behaviour variables.

\section{- $\quad$ Differentiation methods}

The methods which estate agencies use to differentiate themselves from competitive agencies were also investigated. It was found that the differentiation methods used most are total commitment to clients $(80,2$ per cent), best service quality (77,4 per cent), superior market knowledge (57,4 per cent), and involvement in community affairs (39,7 per cent). 
Table 3 Customer behaviour factors covered in training programmes

\begin{tabular}{|l|c|c|c|c|c|}
\hline $\begin{array}{l}\text { Knowledge of customer } \\
\text { behaviour }\end{array}$ & $\begin{array}{c}\text { Not appli- } \\
\text { cable to } \\
\text { our agency } \\
\mathbf{\%}\end{array}$ & $\begin{array}{c}\text { Men- } \\
\text { tioned } \\
\text { briefly } \\
\mathbf{\%}\end{array}$ & $\begin{array}{c}\text { Dis- } \\
\text { cussed } \\
\text { in detail } \\
\text { \% }\end{array}$ & $\begin{array}{c}\text { Mean } \\
\text { So re- } \\
\text { sponse } \\
\%\end{array}$ \\
\hline Buyer's income/financial status & 1,9 & 10,9 & 69,8 & 2,33 & 17,4 \\
\hline $\begin{array}{l}\text { Buyer's reasons for buying property } \\
\text { The influence of the family on buyer } \\
\text { behaviour }\end{array}$ & 1,9 & 14,0 & 66,7 & 2,30 & 17,4 \\
\hline $\begin{array}{l}\text { The effect of the buyer's lifestyle on } \\
\text { buyer behaviour }\end{array}$ & 9,5 & 33,7 & 36,6 & 1,87 & 20,2 \\
\hline $\begin{array}{l}\text { The learning and perceptual ability of } \\
\text { buyers/sellers }\end{array}$ & 7,8 & 36,6 & 34,4 & 1,84 & 21,2 \\
\hline $\begin{array}{l}\text { The role of social demographic } \\
\text { factors (age, language, education, } \\
\text { occupation) in customer behaviour }\end{array}$ & 9,7 & 33,7 & 35,6 & 1,84 & 21,0 \\
\hline $\begin{array}{l}\text { The effect of pressure from social } \\
\text { groups on buyer behaviour }\end{array}$ & 19,5 & 36,2 & 21,6 & 1,57 & 22,7 \\
\hline
\end{tabular}

Cross-tabulations indicate that more than 68 per cent of respondents who indicated that they do marketing research and have superior market knowledge and the best service quality, actually do conduct research into these areas. Unfortunately, approximately 30 per cent of respondents who indicated that they do not do marketing research still maintain that they offer the best service quality and have superior market knowledge. These respondents do not understand the linkage between marketing research and providing the best service quality and superior market knowledge.

\section{- $\quad$ After-sales services}

Respondents were required to indicate the after-sales services their estate agents render. The high means rated for the four-point scale in Table 4 clearly indicate that most respondents make use of the after-sales services listed in the table. For example, the forwarding of a copy of the sales contract to conveyancing attorneys and the purchaser rated a high mean of 3,97, while following up with conveyancing attorneys on progress or problems experienced rated a mean of 3,92 .

The length of time during which the agent keeps contact with clients was also covered in the survey. Of the respondents, 40,1 per cent indicated that they keep contact with respondents for more than a year while eight per cent keep contact for a year, 28,2 per cent for six months, 13,8 per cent for a month and 
5,8 per cent for a week.

Table 4 After-sales services offered by estate agents

\begin{tabular}{|l|c|c|c|c|c|c|}
\hline After-sales services & $\begin{array}{c}\text { Never } \\
\mathbf{\%}\end{array}$ & $\begin{array}{c}\text { Not } \\
\text { sure } \\
\mathbf{\%}\end{array}$ & $\begin{array}{c}\text { Some- } \\
\text { times } \\
\mathbf{\%}\end{array}$ & $\begin{array}{c}\text { Al- } \\
\text { ways } \\
\mathbf{\%}\end{array}$ & $\begin{array}{c}\text { Mean } \\
\text { po res- } \\
\text { ponse } \\
\mathbf{\%}\end{array}$ \\
\hline $\begin{array}{l}\text { Forwarding a signed copy of the contract } \\
\text { of sale to the conveyancing attorneys and } \\
\text { purchaser }\end{array}$ & 0,2 & 0,2 & 1,6 & 96,7 & 3,97 & 1,3 \\
\hline $\begin{array}{l}\text { Following up with the conveyancing } \\
\text { attorneys on the progress/problems } \\
\text { experienced with the transfer in order to } \\
\text { give feedback to the buyer and seller }\end{array}$ & & 0,4 & 6,2 & 92,2 & 3,92 & 1,0 \\
\hline $\begin{array}{l}\text { Informing the seller of progress made in } \\
\text { bond applications/transfer of property }\end{array}$ & 0,2 & 0,4 & 12,3 & 86,4 & 3,86 & 0,7 \\
\hline $\begin{array}{l}\text { Informing the buyer and seller when the } \\
\text { transfer occurs }\end{array}$ & 1,2 & 0,4 & 12,1 & 85,4 & 3,83 & 0,9 \\
\hline $\begin{array}{l}\text { Being available to act as an intermediary } \\
\text { in any disputes which may arise between } \\
\text { the buyer and seller }\end{array}$ & 0,6 & 0,8 & 14,6 & 82,9 & 3,82 & 1,1 \\
\hline $\begin{array}{l}\text { Informing the conveyancing attorney when } \\
\text { the loan application has been submitted }\end{array}$ & 2,5 & 0,8 & 10,3 & 84,8 & 3,80 & 1,6 \\
\hline $\begin{array}{l}\text { Supplying the conveyancing attorneys with } \\
\text { the name of the current bond holder and } \\
\text { account number, as well as the name of the } \\
\text { person or attorneys to contact in this } \\
\text { regard }\end{array}$ & 2,5 & 1,0 & 17,1 & 78,0 & 3,73 & 1,4 \\
\hline $\begin{array}{l}\text { Presenting the buyer with a small gift on } \\
\text { the day of occupation }\end{array}$ & 9,3 & 3,1 & 42,0 & 44,0 & 3,23 & 1,6 \\
\hline $\begin{array}{l}\text { Establishing the whereabouts of the title } \\
\text { deed of the property in order to inform } \\
\text { conveyancing attorneys }\end{array}$ & 14,0 & 1,4 & 34,0 & 47,5 & 3,19 & 3,1 \\
\hline $\begin{array}{l}\text { Keeping contact with the buyer after } \\
\text { occupation (birthdays) }\end{array}$ & 10,3 & 6,6 & 47,3 & 33,5 & 3,07 & 2,3 \\
\hline $\begin{array}{l}\text { Presenting the seller with a small gift after } \\
\text { completion of the transfer }\end{array}$ & 27,4 & 7,8 & 40,5 & 19,3 & 2,55 & 5,0 \\
\hline
\end{tabular}

\section{- $\quad$ Customer service activities and attributes}

Good customer service creates true clients, namely clients who are glad they selected a particular estate agency, customers who will use the estate agency again and positively promote the agency to family and friends who, in turn, may 
become loyal clients. The survey investigated whether estate agencies engage in activities to deliver customer service (see Table 5).

Table 5 Activities to deliver customer service and quality

\begin{tabular}{|c|c|c|c|c|c|c|}
\hline Statements & $\begin{array}{c}\text { Never } \\
\%\end{array}$ & eldom & $\begin{array}{c}\text { Fre- } \\
\text { quently } \\
\%\end{array}$ & $\begin{array}{c}\text { Always } \\
\%\end{array}$ & Mean & $\begin{array}{l}\text { No res- } \\
\text { ponse } \\
\%\end{array}$ \\
\hline $\begin{array}{l}\text { We discuss customer complaints } \\
\text { with estate agents. }\end{array}$ & 2,7 & 4,5 & 20,6 & 67,7 & 3,61 & 4,5 \\
\hline $\begin{array}{l}\begin{array}{l}\text { Estate agents often work together to } \\
\text { deliver high-quality service to } \\
\text { clients. }\end{array} \\
\end{array}$ & 1,2 & 4,9 & 28,8 & 57,8 & 3,54 & 7,3 \\
\hline $\begin{array}{l}\text { Estate agents are involved in the } \\
\text { setting of service quality standards. }\end{array}$ & 2,1 & 4,1 & 32,1 & 54,5 & 3,50 & 7,2 \\
\hline $\begin{array}{l}\text { Estate agents are informed of } \\
\text { marketing plans. }\end{array}$ & 2,1 & 4,5 & 32,1 & 53,1 & 3,48 & 8,2 \\
\hline \begin{tabular}{|l} 
Estate agents are free from \\
restrictions when selling properties.
\end{tabular} & 12,6 & 12,6 & 25,1 & 39,9 & 3,03 & 9,8 \\
\hline $\begin{array}{l}\text { We look at other service industries } \\
\text { to learn more about service quality. }\end{array}$ & 6,8 & 18,9 & 40,9 & 26,7 & 2,94 & 6,7 \\
\hline $\begin{array}{l}\text { Management interact with custo- } \\
\text { mers to determine their experience } \\
\text { with support personnel. }\end{array}$ & 8,8 & 23,0 & 37,9 & 22,0 & 2,80 & 8,3 \\
\hline $\begin{array}{l}\text { There is a formalised feedback sys- } \\
\text { tem with management for estate } \\
\text { agents to share their experiences } \\
\text { with customers. }\end{array}$ & 16,3 & 21,0 & 25,9 & 26,5 & 2,70 & 10,3 \\
\hline $\begin{array}{l}\text { We administer a formal question- } \\
\text { naire immediately after a transaction } \\
\text { about the customer's satisfaction } \\
\text { with estate agents. }\end{array}$ & 42,4 & 27,2 & 11,5 & 9,1 & 1,86 & 9,8 \\
\hline
\end{tabular}

The means in Table 5 reveal that most estate agency firms discuss customer complaints with the estate agents (mean $=3,61$ ). A large number of respondents also indicated that their estate agents work together to deliver quality service (mean $=3,54$ ), that their agents are involved in the setting of service quality standards (mean $=3,50$ ) and that their agents are informed of marketing plans (mean $=3,48)$.

The two activities which were ranked lowest are a formalised feedback system for estate agents to share with management their experiences with customers 
(mean $=2,70)$ and the administration of a formal questionnaire immediately after a transaction about the customer's satisfaction with the estate agent (mean $=1,86)$. When identifying the differentiation methods, the respondents previously ranked the rendering of service quality to buyers as very important, and it is thus surprising that they now ranked these two activities, which are effective in establishing customer needs and satisfaction, as the lowest.

Cross-tabulations reveal that a large percentage of respondents who indicated that they would like to portray an image of excellent customer service, do engage in activities to portray this image. They always discuss customer complaints with agents and their agents collaborate to provide quality service. They therefore seem to realise that these are crucial customer service activities. Unfortunately, less than 60 per cent of the respondents indicated that they engage in other customer service activities whilst wishing to also present an image of excellent customer service. This is worrying since no estate agency can portray an image of customer service excellence if it does not engage in all the crucial customer service activities, instead of only some of them.

\section{- $\quad$ Corporate climate and internal marketing}

Employees in the estate agency should be well trained in customer service and be aware of the fact that their own job satisfaction ultimately rests on the success of the agency in the market. Before an estate agency can generate satisfied and loyal customers, it must first ensure employee satisfaction and loyalty through the intensive management of internal relationships.

The results of the survey reveal that the majority of respondents apply internal marketing activities such as evaluating advertising campaigns by consulting employees, discussing marketing plans with their employees and training employees to deal with customers. The survey also reveals that the majority of respondents strive to create a positive corporate culture in their agencies. For instance, they agree that all agents are always free to communicate their views to management and that everyone in the agency realises that the needs of clients are their priority.

\section{- $\quad$ Customer complaints}

The policies of respondents on customer complaints were tested in the survey. Table 6 shows that complaints are referred to management in 77,2 per cent of the agencies. In 62,8 per cent of the agencies, complaints are discussed at meetings and in 67,3 per cent of the cases recurring complaints are investigated thoroughly. Only eight per cent of the respondents indicated that a complaint book or list is kept for future reference, while a meagre 5,1 per cent indicated that they have no policy on customer complaints. 
Table 6 Customer complaints

\begin{tabular}{|l|l|l|}
\hline \multicolumn{1}{|c|}{ Policies } & \multicolumn{2}{c|}{ Percentage } \\
\hline & $\begin{array}{c}\text { Frequency } \\
\text { \% }\end{array}$ & $\begin{array}{c}\text { No } \\
\text { response }\end{array}$ \\
\hline We have no such policy & 5,1 & 94,9 \\
\hline Complaints are dealt with by the agent involved & 52,7 & 47,3 \\
\hline Complaints are referred to management & 77,2 & 22,8 \\
\hline A complaint book/list is kept for future reference & 8,0 & 92,0 \\
\hline Complaints are often discussed at meetings & 62,8 & 37,2 \\
\hline Recurring complaints are investigated thoroughly & 67,3 & 32,7 \\
\hline
\end{tabular}

(Multiple answers were obtained from respondents.)

\section{CONCLUSIONS AND RECOMMENDATIONS}

All the objectives of the study were accomplished and the main findings are summarised below.

The results of the study indicate that although a large percentage of the agencies indicated that they have mission statements, only seven have mission statements which meet some of the requirements for mission statements. The agencies seem to regard a mission statement as a slogan or objective. It can thus be concluded that the majority of respondents do not know what a mission statement is, leaving much room for education in this regard. Such training could result in eliminating any uncertainty in terms of the basic purpose for the existence of the agency and what it should work towards in the light of longrange opportunity and the overall survival of the agency.

When selecting and appointing new agents, the majority of agencies consider service orientation as important. It was, however, disconcerting to find that estate agencies are not overly concerned about qualifications (eg. completion of the Board examinations) and previous experience in the real estate field when appointing new agents, since these are factors which could influence the way agents interact with clients as well as the services they provide to customers. Where training is concerned, the survey reveals that the majority of respondents train estate agents themselves, with the resultant threat of in-breeding. During training, the majority of agencies concentrate on topics such as qualifying the buyer or seller, after-sales contact with the buyer or seller and the building of long-term relationships with clients. These are encouraging findings since these topics are key components of customer service. The findings reveal that the two 
customer behaviour factors covered most in training are income or financial status and the buyer's reasons for buying the property. Unfortunately, none of the other customer behaviour influences are discussed in great detail during the training of estate agents. Cross-tabulations also reveal that respondents focus more on the buyer's financial position than on his needs and the consumer behaviour influences.

Estate agencies need to be made aware of the importance of appointing agents with experience and training, since they tend to be better informed of the correct steps to take when selling a home, as well as of the principles of customer service, resulting in hopefully higher levels of customer satisfaction.

The differentiation methods used most by both groups of respondents are total commitment to clients, best service quality and superior market knowledge. Cross-tabulations reveal that a large percentage of the agencies do not research these areas of differentiation. Although these respondents are of the opinion that they offer the best service quality and have superior market knowledge, it is impossible to do so without in-depth knowledge obtained by thorough marketing research. Estate agencies should therefore do more research into areas such as delivering quality service and the market as this will enable them to better analyse the needs of customers and thus to render good customer service and strengthen relationships with customers.

The survey results indicate that the majority of agencies engage in activities to ensure customer service, for example, they discuss customer complaints with estate agents, their agents work together to render quality service and also help to formulate quality standards. It is surprising that the two activities ranked the lowest, are a formalised feedback system for agents to share experiences with management and administration of a formal questionnaire after a transaction to test customer satisfaction. If estate agencies make use of formal feedback systems and questionnaires to test clients' satisfaction with their services, they can adapt their strategies to the needs of customers and thus provide a better quality service, hopefully resulting in long-term relationships with clients.

The survey reveals positive findings in terms of corporate climate and internal marketing. The results reveal that the majority of agencies engage in internal marketing activities. Most of the agencies, for instance, evaluate advertising campaigns by consulting employees, discuss marketing plans with employees and train them to deal with customers. The majority of agencies also strive to create a positive corporate culture. Respondents indicated that all agents are free to communicate their views to management and that everyone in the agency realises that the needs of clients are their priority. 
In conclusion it can be stated that estate agencies seem to be aware of the importance of providing good customer service and of being service oriented, but they do not always seem to realise the need to conduct marketing research and test the actual satisfaction of customers with the services provided, leaving a potential gap between what the customer wants and what the estate agency provides.

\section{ENDNOTE}

1 In this article, for stylistic purposes, any reference to one gender shall include the other gender.

\section{REFERENCES}

1 ANON (2000) "Finance and manage your home loan” July/August: 11.

2 BENNETT, J.A. \& STRYDOM, J.W. (2001) Introduction to Travel and Tourism Marketing, Juta: Lansdowne.

3 CHRISTOPHER, M., PAYNE, ASS. \& BALLANTYNE, D. (1991) Relationship Marketing, Butterworth: Oxford.

4 CHEALES, P. (2000) I Was your Customer, Johannesburg: Zebra Press.

5 CLEGG, B. (2000) The Invisible Customer, Kogan Page: London.

6 FINANCE WEEK (2002) "Do your sums before you upgrade”, 8 March: 13.

7 FUTRELL, C.M. (2000) ABCs of Relationship Selling, McGraw-Hill: Singapore.

8 GRÖNROOS, C. (2000) Service Management and Marketing, Wiley: New York.

9 GUMMESSON, E. (2000) Total Relationship Marketing, Butterworth: Woburn.

10 JANKOWICZ, A.D. (2001) Business Research Projects, (3 ${ }^{\text {rd }}$ ed.) Business Press: London.

11 KOTLER, P. (2000) Marketing Management. The Millennium Edition, Prentice Hall: New Jersey.

12 KURTZ, D.L. \& CLOW, K.E. (1998) Services Marketing, Wiley: New York.

13 LEWISON, D.M. (1997) Retailing, New York: Macmillan.

14 PRIDE, W.M. \& FERRELL, O.C. (2000) Marketing Concepts and Strategies, Houghton Mifflin: Boston.

15 READERS DIGEST (2000) "Estate agents still ripping us off?”, May: 107. 
16 STRYDOM, J.W., JOOSTE, C.J. \& CANT, M.C. (2000) Marketing Management, Juta: Kenwyn.

17 SUNDAY TIMES (2002) "Residential sector shrugs off interest blow", Business Times, 3 March: 21.

18 TRUTER, C. (1993) The Real Estate Industry, Van Schaik: Pretoria. 